\title{
Evaluasi Tiga Metode Preparasi RNA Total untuk Deteksi Turnip mosaic potyvirus dari Benih Brassica rappa dengan Reverse Transcription-Polymerase Chain Reaction
}

\author{
Evaluation of Three Total RNA Preparation Methods for Detection \\ of Turnip mosaic virus from Brassica rappa Seeds using \\ Reverse Transcription-Polymerase Chain Reaction
}

\author{
Jati Adiputra ${ }^{1}$, Sri Hendrastuti Hidayat ${ }^{2}$, Tri Asmira Damayanti ${ }^{2 *}$ \\ ${ }^{1}$ Balai Besar Uji Standar Karantina Pertanian, Jakarta 13220 \\ ${ }^{2}$ Institut Pertanian Bogor, Bogor 16680
}

\begin{abstract}
ABSTRAK
Turnip mosaic virus (TuMV) merupakan virus tular benih yang penting pada Brassicae di Indonesia. Metode deteksi yang akurat dan terpercaya diperlukan untuk mendeteksi virus tersebut dari benih sehingga kejadian penyakit dapat dihindari sedini mungkin. Penelitian dilakukan untuk mengevaluasi metode ekstraksi RNA total tanaman untuk mendeteksi TuMV menggunakan teknik reverse transcriptionpolymerase chain reaction. Tiga metode ekstraksi RNA total yang dievaluasi terdiri atas metode ekstraksi Wylie, Randles, dan kit komersial. Bahan tanaman yang digunakan ialah benih dan kecambah caisin (Brassica rappa) yang berumur 3, 5, dan 7 hari. RNA total yang diperoleh dari ekstraksi menggunakan metode Wylie dan Randles memiliki konsentrasi yang tinggi dengan kemurnian yang rendah, sedangkan RNA total hasil ekstraksi menggunakan kit komersial memiliki konsentrasi rendah dan kemurnian tinggi. TuMV dari benih berhasil terdeteksi menggunakan metode ekstraksi Wylie dan Randles, TuMV dari kecambah berumur 3 hari berhasil terdeteksi menggunakan ketiga metode, TuMV dari kecambah berumur 5 hari hanya terdeteksi menggunakan metode Randles, dan TuMV dari kecambah berumur 7 hari tidak dapat terdeteksi menggunakan ketiga metode. Ekstraksi RNA total menggunakan metode Wylie dan Randles dapat direkomendasikan untuk mendeteksi TuMV dari benih caisin dengan teknik RT-PCR.
\end{abstract}

Kata kunci: benih caisin, Brassica rappa, reverse transcription- polymerase chain reaction, RNA total, Turnip mosaic potyvirus

\begin{abstract}
Turnip mosaic virus (TuMV) is an important seedborne virus that infects vegetable crops, especially Brassicae group, in Indonesia. Reliable detection method having high accuracy is required to detect the virus from seeds in order to avoid disease incidence as early as possible. A study was conducted to evaluate three total RNA extraction methods from Brassica seeds for TuMV detection using reverse transcription- polymerase chain reaction. The samples used are Brassica rappa seeds and seedling germinated for 3, 5, and 7 days. Total RNA extraction methods evaluated consisted of Wylie method, Randles method, and commercial kit as comparation. Total RNA extracted using Wylie and Randles methods has high concentration but low level of purity, on the other hand total RNA obtained using commercial kit has low concentration but high level of purity. Detection of TuMV from seed was
\end{abstract}

*Alamat penulis korespondensi: Departemen Proteksi Tanaman, Fakultas Pertanian, Institut Pertanian Bogor, Jalan Kamper, Kampus IPB, Darmaga, Bogor 16680

Tel: 0251-8629364, Faks: 0251-862962, Surel: triadys@ipb.ac.id 
successfully carried out using Wylie and Randles methods, TuMV from 3 - day old seedlings was detected using all three methodes, TuMV from 5-day old seedlings was only detected using Randles method, whereas TuMV from 7-day old seedlings was not detected using all three methodes. Total RNA extraction method using Wylie and Randles methodes is recommended for detection of TuMV from caisin seed using RT-PCR technique.

Key words: Brassica rappa seed, reverse transcription- polymerase chain reaction, Total RNA, Turnip mosaic potyvirus

\section{PENDAHULUAN}

Turnip mosaic potyvirus (TuMV) merupakan virus penting yang menginfeksi sayur-sayuran famili Brassicae dan dapat juga menginfeksi tanaman dari famili yang lain. Selain menyebabkan penurunan hasil, TuMV juga mempengaruhi kualitas produk yang dihasilkan. TuMV tersebar secara luas di dunia dan menyebar cepat di lapangan melalui kutudaun secara nonpersisten (Sanchez et al. 2002) dan melalui benih (Kartiningtyas dan Hidayat 2006). Rusli et al. (2007) melaporkan bahwa sawi hijau dan lobak di Jawa Barat, Jawa Tengah, Jawa Timur, dan Bali telah terinfeksi oleh TuMV.

Sumber infeksi TuMV di lapangan dapat berasal dari sumber inokulum yang ada di lapangan atau dari benih yang membawa virus. Keberhasilan mendeteksi infeksi virus sejak dini merupakan strategi yang tepat dalam strategi pengendalian penyakit. Badan Karantina Pertanian melakukan deteksi virus pada benih impor yang masuk ke wilayah Indonesia umumnya menggunakan metode double antibody sandwich enzime-linked immunosorbent assay (DAS-ELISA). Metode tersebut sering digunakan karena mudah cara kerjanya, tidak membutuhkan antibodi dan konjugat yang terlalu banyak, dan sesuai untuk jumlah sampel yang banyak (Khan et al. 2003). Metode deteksi virus tumbuhan lain yang dapat digunakan untuk TuMV adalah metode reverse transcription-polymerase chain reaction (RT-PCR). Metode RT-PCR memiliki keunggulan karena mempunyai spesifikasi dan sensitifitas yang tinggi sehingga dapat mendeteksi patogen dengan titer/jumlah yang sedikit (Ward et al. 2004).
Namun metode ini memiliki kekurangan, yaitu keberadaan senyawa inhibitor pada ekstrak RNA total tanaman yang dapat mempengaruhi proses amplifikasi DNA target (Ma dan Yang 2011). Oleh karena itu, pemilihan metode ekstraksi RNA yang tepat sangat berpengaruh terhadap keberhasilan deteksi RNA virus pada jaringan tanaman.

Penelitian dilakukan untuk mengevaluasi metode ekstraksi RNA total metode ekstraksi Wylie, dan Randles untuk mendeteksi TuMV daribenih caisin (Brassicarappa) menggunakan teknik RT-PCR. Sebagai pembanding dilakukan ekstraksi menggunakan kit komersial yang merupakan metode umum yang dilakukan oleh Balai Besar Uji Standar Karantina Pertanian (BBUSKP). Metode ekstraksi RNA menggunakan kit komersial sangat praktis, tetapi umumnya disarankan untuk ekstraksi RNA asal jaringan daun atau kecambah, sedangkan untuk benih belum banyak dilaporkan.

\section{BAHAN DAN METODE}

\section{Penyiapan Bahan Tanaman}

Ekstraksi RNA total tanaman dilakukan menggunakan benih dan kecambah caisin. Benih caisin sebanyak 1200 butir langsung digerus menggunakan nitrogen cair di dalam mortar, selanjutnya hasil penggerusan yang berupa bubuk dipisahkan menjadi tiga bagian (untuk tiga metode ekstraksi). Sebanyak 200 butir benih caisin dikecambahkan pada sebuah wadah plastik di atas kertas tisu basah. Kecambah berumur 3, 5, dan 7 hari digunakan sebagai bahan ekstraksi RNA total. 


\section{Ekstraksi RNA Total}

Ekstraksi RNA total tanaman dari benih dan kecambah caisin dilakukan mengikuti metode Wylie (Wylie et al. 1993), metode Randles (Hodgson et al. 1998), dan kit komersial (RNeasy plant mini kit). Ekstraksi RNA total mengikuti metode Wylie diawali dengan menggerus sampel benih atau kecambah sebanyak $0.1 \mathrm{~g}$ dalam $500 \mu \mathrm{L}$ bufer ekstrak (Tris- $\mathrm{HCl} 50 \mathrm{mM}, \mathrm{pH} 8.5$, EDTA $10 \mathrm{mM}, \mathrm{NaCl} 200 \mathrm{mM}$ ) dan $500 \mu \mathrm{L}$ phenol chloroform isoamilalcohol (PCI). Larutan dicampur hingga homogen dan disentrifugasi selama 1 menit dengan kecepatan 13000 x g. Supernatan dipisahkan, kemudian ditambah chloroform isoamilalcohol (CI) (50:1) sebanyak 1 volume supernatan, dan dilanjutkan dengan sentrifugasi pada kecepatan 13000 x g selama 1 menit. Supernatan yang diperoleh ditambah 1 volume isoproponal, lalu diinkubasi pada suhu $-20{ }^{\circ} \mathrm{C}$ selama satu malam. Supernatan yang sudah diinkubasi disentrifugasi pada kecepatan 13000 x g selama 3 menit, hingga terbentuk pelet. Pelet dilarutkan dengan penambahan $100 \mu \mathrm{L}$ bufer TE (Tris$\mathrm{HCl} 10 \mathrm{mM}, \mathrm{pH}$ 7.4, EDTA $1 \mathrm{mM}), 4 \mu \mathrm{L}$ $5 \mathrm{M} \mathrm{NaCl}$, dan $250 \mu \mathrm{L}$ etanol $96 \%$, kemudian diinkubasi di dalam es selama 20 menit. Supernatan selanjutnya disentrifugasi selama 3 menit pada kecepatan $13000 \times$ g sehingga diperoleh pelet, setelah dikeringanginkan pelet disuspensi dalam $50 \mu \mathrm{L}$ air bebas RNase.

Ekstraksi RNA total mengikuti metode Randles diawali dengan menggerus sampel benih atau kecambah yaitu sebanyak $0.1 \mathrm{~g}$ dalam $800 \mu \mathrm{L}$ bufer NETM $(2 \mathrm{M} \mathrm{NaCl}$, $100 \mathrm{mM}$ sodium asetat, $10 \mathrm{mM}$ EDTA, $50 \mathrm{mM}$ Tris- $\mathrm{HCl}[\mathrm{pH} 7.5], 0.25 \%$ [v/v] 2merkaptoetanol), $40 \mu \mathrm{L} 20 \%(\mathrm{w} / \mathrm{v})$ sodium dodecyl sulfate (SDS); selanjutnya diinkubasi pada suhu $25{ }^{\circ} \mathrm{C}$ selama 30 menit, ditambah $750 \mu \mathrm{L}$ PCI (25:24:1), dan disentrifugasi pada kecepatan 10000 x g selama 15 menit. Supernatan dipindahkan ke tabung baru dan ditambahkan 1 volume isopropanol, disentrifugasi pada kecepatan $11000 \mathrm{x}$ g selama 15 menit dan selanjutnya peletnya dicuci dengan etanol 70\%, dikeringanginkan, lalu dilarutkan dalam $50 \mu \mathrm{L}$ air bebas RNase.

Sebagai pembanding metode ekstraksi total RNA dari sampel benih dan kecambah juga dilakukan menggunakan RNeasy plant mini kit sesuai prosedur (Qiagen, Jerman).

\section{Kuantifikasi Hasil Ekstraksi RNA}

Total RNA hasil ekstraksi diukur kemurnian dan konsentrasinya menggunakan spektrofotometer (Perkin Elmer, USA) pada panjang gelombang 260 dan $280 \mathrm{~nm}$. Pengukuran konsentrasi RNA dilakukan pada absorbansi $260 \mathrm{~nm}$ dengan perhitungan 1 nilai absorbansi sama dengan $40 \mu \mathrm{g} \mathrm{mL}^{-1}$. Kemurnian RNA diukur pada nisbah A260/ A280 karena protein diserap pada panjang gelombang $280 \mathrm{~nm}$ (Aranda et al. 2009).

\section{Sintesis dan Amplifikasi Complementary DNA}

RNA total hasil ekstraksi digunakan sebagai cetakan untuk proses sintesis complementary DNA (cDNA) dalam total volume $10 \mu \mathrm{L}$. Komposisi bahan untuk sintesis cDNA terdiri atas $1 \mu \mathrm{L} 10 \mathrm{x}$ bufer untuk M-MuLV (New England Biolabs Inc., Beverly, MA), $0.2 \mu \mathrm{L} 10 \mathrm{mM}$ dNTP(s) (Novagen), $0.75 \mu \mathrm{L} 10 \mu \mathrm{M}$ Oligo d(T), $0.32 \mu \mathrm{L}$ RNase OUT (40U $\mu \mathrm{L}^{-1}$ ) (Invitrogen), $0.32 \mu \mathrm{L}$ M-MuLV reverse transcriptase $\left(200{\left.\mathrm{U} \mu \mathrm{L}^{-1}\right)}^{-1}\right.$ (New England Biolabs Inc., Beverly, MA), $4.41 \mu \mathrm{L}$ air bebas RNase dan $3 \mu \mathrm{L}$ total RNA. Tahapan sintesis cDNA dilakukan dalam thermal cycler (Thermo Hybaid) dengan program $25^{\circ} \mathrm{C}$ selama 5 menit, $37^{\circ} \mathrm{C}$ selama 90 menit, dan $70^{\circ} \mathrm{C}$ selama 15 menit. Tahapan amplifikasi cDNA dilakukan menggunakan Promega ${ }^{\circledR}$ Go Taq green master mix dengan total volume $25 \mu \mathrm{L}$ dan komposisi premix PCR sesuai petunjuk produsen (Promega). Primer yang digunakan ialah TuMV 8573F (5'-AGCTCCCTAGCACAAGAAGG-3') dan TuMV 9385R (5'-TCGAGCTAAGCA CATGTCGG-3') yang mengamplifikasi potongan gen $\mathrm{NIb}$ dan selubung protein (Nicolas dan Laliberta 1992). Sebagai kontrol internal digunakan primer nad5F (5'-GATGCTTCTTGGGGCTTCTTGTT-3') 
dan nad5R (5'-CTCCAGTCACCAACATT GG-3') yang mendeteksi gen NADH dehydrogenase subunit 5 (Nad5) mRNA tanaman (Menzel et al. 2002).

Amplifikasi cDNA dilakukan dalam thermal cycler (Thermo Hybaid) dengan 1 siklus pada suhu $95{ }^{\circ} \mathrm{C}$ selama 5 menit, 30 siklus pada suhu $95{ }^{\circ} \mathrm{C}$ selama 30 detik, suhu $50{ }^{\circ} \mathrm{C}$ selama 90 detik, suhu $72{ }^{\circ} \mathrm{C}$ selama 60 detik, terakhir adalah tahap ekstensi pada suhu $72{ }^{\circ} \mathrm{C}$ selama 10 menit. Hasil amplifikasi kemudian divisualisasi menggunakan gel agarosa konsentrasi 1.5\% dalam bufer TAE, menggunakan voltase 75 Volt selama 65 menit, dan direndam dalam etidium bromida konsentrasi 10\% selama 30 menit.

\section{HASIL}

\section{Konsentrasi dan Kemurnian RNA Hasil Ekstraksi}

Kualitas RNA total hasil ekstraksi diukur menggunakan spektrofotometer untuk mengetahui konsentrasi dan kemurniannya. Dibandingkan dengan metode lainnya metode Randles menghasilkan RNA total dengan konsentrasi tertinggi, terutama pada hasil

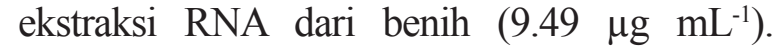
Konsentrasi RNA total yang diekstraksi dengan metode Wylie memberikan hasil yang cukup tinggi yaitu antara $7.97-9.01 \mu \mathrm{g}$ $\mathrm{mL}^{-1}$, sedangkan RNA total yang diekstraksi menggunakan kit komersial menunjukkan konsentrasi paling rendah $(2.92-7.52 \mu \mathrm{g}$ $\mathrm{mL}^{-1}$ ) (Tabel 1).
Pengukuran kemurnian RNA hasil ekstraksi memberikan hasil yang tidak berbanding lurus dengan konsentrasi RNA (Tabel 1). Metode Randles menghasilkan RNA dengan konsentrasi yang cukup tinggi, tetapi RNA yang dihasilkan memiliki nilai kemurnian yang paling rendah. Sebaliknya kit komersial menghasilkan RNA dengan rata-rata kemurnian yang paling tinggi, walaupun konsentrasi RNA total lebih rendah dibandingkan dengan dua metode ekstraksi lainnya. Pengukuran kemurnian RNA pada nisbah A260/A280 seharusnya memberikan nilai 2.0 untuk menunjukkan bahwa sampel RNA yang diekstrak telah murni dari protein (Aranda et al. 2009). Metode ekstraksi dengan kit komersial untuk kecambah 5 hari memberikan nilai kemurnian 2.27.

\section{Deteksi TuMV pada Benih Caisin dengan RT-PCR}

Hasil positif deteksi TuMV dengan teknik RT-PCR menggunakan pasangan primer 8573F/9385R ditandai dengan munculnya pita DNA berukuran $800 \mathrm{pb}$ (Gambar 1). Deteksi TuMV dari benih caisin menggunakan metode Wylie dan Randles memberikan hasil positif, sedangkan menggunakan kit komersial memberikan hasil negatif. Tingkat keberhasilan deteksi TuMV dari benih caisin menggunakan metode Wylie, Randles, dan kit komersial berturut-turut ialah $100 \%$ (6/6), 50\% (3/6), dan 0\% (0/6). Keberadaan TuMV pada kecambah caisin berumur 3 hari berhasil terdeteksi menggunakan ketiga metode ekstraksi, sedangkan pada kecambah

Tabel 1 Konsentrasi $\left(\mu \mathrm{g} \mathrm{mL}^{-1}\right)$ dan kemurnian RNA total yang diekstraksi dari benih dan kecambah caisin menggunakan tiga metode ekstraksi

\begin{tabular}{|c|c|c|c|c|c|c|}
\hline \multirow{2}{*}{ Sampel } & \multicolumn{3}{|c|}{ Konsentrasi ${ }^{\text {a }}$} & \multicolumn{3}{|c|}{ Kemurnian $^{\mathrm{b}}$} \\
\hline & Wylie & Randles & Kit Komersial & Wylie & Randles & Kit Kc \\
\hline $\mathrm{B}$ & $8.28 \pm 0$ & $9.49 \pm 0.57$ & $2.92 \pm 0.40$ & $1.51 \pm 0.14$ & $1.39 \pm 0.10$ & $2.27=$ \\
\hline Kecam & $92 \pm$ & $8.64 \pm 0.13$ & 3.91 & $1.29=$ & 1.15 & 1.74 \\
\hline Keca & $7.97 \pm 0.56$ & $8.19 \pm 0.16$ & $6.30=$ & $1.59 \pm$ & 1.12 & $1.90=$ \\
\hline Kecambah 7 hari & $9.01 \pm 0.44$ & $9.38 \pm 0.21$ & $7.52 \pm 0.85$ & $1.23 \pm 0.05$ & $1.17 \pm 0.01$ & $1.67 \pm 0.08$ \\
\hline
\end{tabular}

${ }^{\mathrm{a}}$ Konsentrasi diukur pada gelombang $260 \mathrm{~nm} \times 40 \mu \mathrm{gmL}^{-1},{ }^{\mathrm{b}}$ Kemurnian diukur dengan menghitung rasio absorbansi pada panjang gelombang $260 \mathrm{~nm}$ dan $280 \mathrm{~nm}$, ' Standar deviasi 

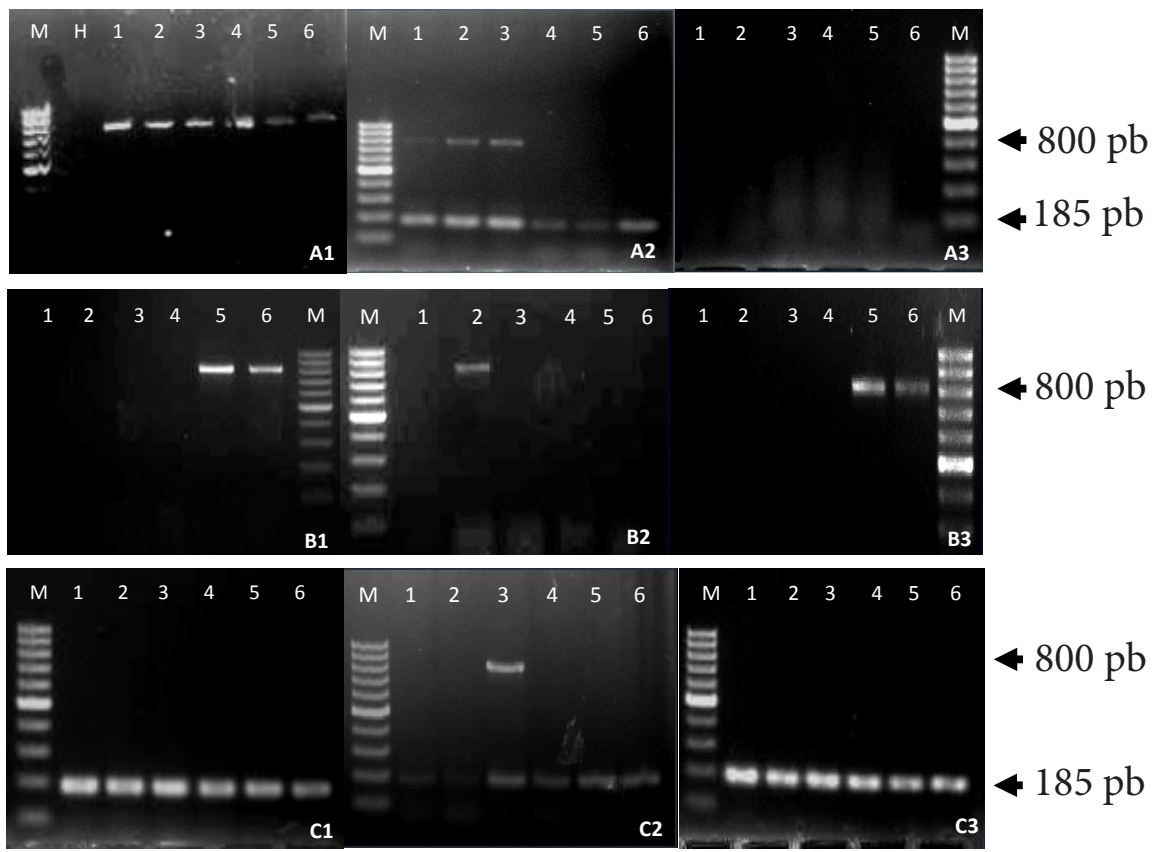

Gambar 1 Elektroforesis DNA hasil RT-PCR TuMV dari benih (A) dan kecambah caisin umur 3 hari(B) dan umur 5 hari (C). Preparasi RNA totalmenggunakan metode Wylie(A1,B1,C1), metode Randles (A2, B2, C2), dan RNeasy kit (A3, B3, C3). Dupleks RT-PCR menggunakan primer spesifik TuMV dan internal kontrol Nad5 (A2, C1, C2, C3). H, kontrol sehat; M, penanda DNA 100 pb.

caisin berumur 5 hari hanya berhasil terdeteksi menggunakan metode Randles. Pada kecambah berumur 7 hari, TuMV tidak berhasil terdeteksi dari RNA total yang diekstraksi menggunakan ketiga metode ekstraksi tersebut (data tidak diperlihatkan).

Sebagai kontrol internal pada evaluasi metode ekstraksi RNA total dari benih dan kecambah caisin digunakan sepasang primer nad5F/nad5R dalam tahapan RT-PCR. Pita DNA berukuran $185 \mathrm{pb}$ merupakan hasil amplifikasi bagian gen NADH pada mRNA tanaman menggunakan primer tersebut (Gambar 1). Munculnya pita DNA berukuran 185 pb merupakan indikasi keberhasilan ekstraksi RNA total tanaman menggunakan masing-masing metode ekstraksi. Pita DNA berukuran $185 \mathrm{pb}$ tidak berhasil teramplifikasi pada metode kit komersial untuk sampel benih dan kecambah berumur 5 hari, sedangkan ekstraksi RNA total dengan metode Wylie dan Randles berhasil mengamplifikasi pita DNA berukuran $185 \mathrm{pb}$.

\section{PEMBAHASAN}

Keberhasilan deteksi virus menggunakan teknik RT-PCR ditentukan oleh penyediaan materi asam nukleat (RNA) dengan konsentrasi dan kemurnian yang baik. Menurut Li et al. (2008) konsentrasi RNA yang tinggi dan jumlah inhibitor yang rendah menentukan keberhasilan teknik RT-PCR dalam mendeteksi patogen. Metode Wylie menghasilkan RNA dengan konsentrasi dan kemurnian yang baik sehingga deteksi TuMV memberikan hasil positif baik dari benih maupun dari kecambah caisin. Ekstraksi RNA dengan metode Wylie menggunakan senyawa fenol/kloroform/isoamilalkohol (PCI) dan penambahan CI yang berfungsi untuk menghilangkan protein, lipid dan polisakarida dari larutan RNA, serta meningkatkan jumlah RNA yang dihasilkan (Ma dan Yang 2011). Berbeda dengan metode Randles yang hanya menggunakan PCI tanpa penambahan CI sehingga hasil ekstraksi RNA memberikan konsentrasi dan kemurnian yang lebih rendah. Ekstraksi RNA dengan kit komersial 
mengandalkan kerja membran silika untuk mengikat RNA total tanaman dan kemudian mencuci inhibitor-inhibitor melalui membran tersebut sehingga dihasilkan RNA dengan kemurnian yang tinggi. Walaupun demikian Li et al. (2008) melaporkan bahwa kit komersial tidak selalu memberikan hasil amplifikasi yang baik untuk semua jenis bahan tanaman. Hasil ekstraksi RNA dari benih dan kecambah caisin menggunakan kit komersial memiliki kemurnian yang tinggi, tetapi konsentrasi sangat rendah sehingga TuMV tidak berhasil teramplifikasi.

Secara umum metode Wylie memberikan hasil yang terbaik untuk mendeteksi TuMV dari benih dan kecambah caisin. Hasil yang sama dilaporkan oleh Wylie et al. (1993) yang berhasil mendeteksi CMV dari benih kacang-kacangan dan serealia. Metode Wylie memiliki tahapan ekstraksi yang tidak terlalu banyak dan hanya membutuhkan bahan dalam jumlah yang sedikit. Kekurangan metode ini ialah waktu pengerjaan yang cukup panjang karena harus melalui beberapa tahapan inkubasi. Modifikasi suhu dan waktu inkubasi dapat diujicobakan untuk mempersingkat waktu pengerjaan.

Duplex RT-PCR, yaitu amplifikasi dua target DNA menggunakan dua pasang primer dalam satu reaksi, sangat disarankan untuk memperkuat validasi hasil pengujian. Penggunaan kontrol internal dengan primer nad5F/nad5R memastikan tidak terjadi kesalahan teknis pada tahap ekstraksi RNA dan amplifikasi cDNA.

\section{DAFTAR PUSTAKA}

Aranda IVR, Dineen S, Craig RL, Guerrieri RA, Robertson JM. 2009. Comparison and evaluation of RNA quantification methods using viral, prokaryotic, and eukaryotic RNA over a 104 concentration range. Anal Biochem. 387(1):122-127. doi: 10.1016/j. ab.2009.01.003.

Hodgson RAJ, Wall GC, Randles JW. 1998. Specific identification of Coconut tinangaja viroid for differential field diagnosis of viroids in coconut palm. Phytopathology. 88(8):774-781. doi: 10.1094/ PHYTO.1998.88.8.774.

Kartiningtyas, Hidayat SH. 2006. Deteksi Turnip mosaic virus dalam jaringan benih dan daun. J HPT Tropika. 6(1):32-40.

Khan MS, Hoque MI, Sarker RH, Muehlbach HP. 2003. Detection of important plant viruses in invitro regenerated potato plants by double antibody sandwich method of ELISA. Plant Tissue Cult. 13(1):21-29.

Li R, Mock R, Huang Q, Abad J, Hartung J, Kinard G. 2008. A reliable and inexpensive method of nucleic acid extraction for the PCR-based detection of diverse plant pathogen. J Virol Methods. 154(2-3):55-58. doi:10.1016/j.jviromet.2008.09.008.

Ma XB, Yang J. 2011. An optimized preparation method to obtain high-quality RNA from dry sunflower seeds. Genet Mol Res. 10(1):160168. doi: 10.4238/vol10-1 gmr979.

Menzel W, Jelkmann W, Maiss E. 2002. Detection of four apple viruses by multiplex RT-PCR assay with coamplification of plant mRNA as internal control. J Virol Methods. 99(1-2):81-92.

Nicolas O, Laliberte JF. 1992. The complete nucleotide sequence of Turnip mosaic potyvirus RNA. J Gen Virol. 73(11):27852793. doi: 10.1099/0022-1317-73-11-2775.

RusliES, HidayatSH, Suastika G, Kartosuwondo U. 2007. Kisaran dan keragaman gejala infeksi Turnip mosaic virus. J Perlin Tan Indones. 13:22-34.

Sanchez F, Wang X, Jenner CE, Walsh JA, Ponz F. 2002. Strains of Turnip mosaic virus as defined by the molecular analysis of the coat protein gene of the virus. Virus Res. 94:3334. doi: 10.1016/SO168-1702(03)00122-9.

Ward E, Foster SJ, Fraaije BA, Mc Cartney HA. 2004. Plant pathogen diagnostics: immunological and nucleic acid-based approaches. Ann Appl Biol. 145(1):1-16. doi: 10.1111/j.1744-7348.2004.tb00354x.

Wylie S, Wilson CR, Jones RAC, Jones MGK. 1993. A polymerase chain reaction assay for Cucumber mosaic virus in lupin seeds. Aust J Agri Res. 44:41-51.doi: 10.1071/AR9930041. 